— реализация своих возможностей и способностей, что принесет больше пользы государству.

Существуют множество форм и способов нематериального стимулирования персонала:

- слова благодарности;

- поздравления сотрудников с важными днями, с увеличением его трудового стажа и т.д.;

- организация спортивных соревнований [4].

Таким образом, создание эффективной системы стимулирования труда государственных служащих требует интеграции нематериальных и материальных стимулов за труд, что приведет к развитию моральной приверженности сотрудников и повышению качества их профессиональной деятельности.

$$
* * *
$$

1. Акимова Е.Ю. Проблема имиджа государственных служащих в современном обществе. - [Электронный pecypc]. - Режим доступа: http://vestnik.yspu.org/releases/2011_1pp/52.pdf

2. Анощенков А.В. Мотивация государственных гражданских служащих // Молодой ученый. - 2019. - №20. C. $187-189$.

3. Луковцева Е.Н. Формирование эффективной системы мотивации для государственных гражданских служащих // Лидерство и менеджмент. - 2017. - Т. 4. - №4. - С. 207-219.

4. Лымарева О.А., Жуков Н.Е., Щербина И.С. Анализ системы мотивации труда служащих в зарубежных и отечественных государственных структурах // Экономика устойчивого развития. - 2020. - №2.- С. 138-141.

\title{
Юсупова Т.А. \\ Особенности применения методов стимулирования персонала в сфере государственного управления
}

ФГБОУ ВО «Чеченский государственный университет имени А.А.Кадырова»

(Россия, Грозньй)

doi: 10.18411/trnio-11-2021-120

\section{Аннотация}

Государственное управление имеет важное значение для функционирования общества. Качество и образ жизни всего населения напрямую зависят от работы структуры государственного аппарата. Недавно правительство приняло новые меры по совершенствованию административной структуры, что положительно сказалось на деятельности всей государственной власти. Чтобы поддерживать мотивацию к работе в этих структурах, необходимы современные методы стимулирования деятельности сотрудников.

Ключевые слова: стимулирование, мотивация, государственное управление, персонал, администрирование.

\section{Abstract}

Public administration is essential for the functioning of society. The quality and lifestyle of the entire population directly depend on the work of the structure of the state apparatus. Recently, the government has taken new measures to improve the administrative structure, which has a positive impact on the activities of the entire government. To maintain motivation to work in these structures, modern methods of stimulating the activities of employees are needed.

Keywords: stimulation, motivation, public administration, personnel, administration.

Международное сообщество уделяет пристальное внимание эффективному функционированию общественных услуг, поскольку оно имеет неоспоримое значение для жизни любого общества. Однако для России это самый актуальный вопрос. Это связано с огромной территорией, большим населением и необоснованно раздутой бюрократией, 
ставшей наследием Советского Союза. Для решения существующих проблем требуется большое количество ресурсов. Содержание государственного аппарата. Услуги требуют огромных вложений со стороны государства, а из-за неправильной организации работы государство часто не может обеспечить ожидаемых результатов.

С другой стороны, важным фактором изменения системы управления является использование новейших национальных кадровых организаций и методов работы. Учреждения помогают улучшить качество сотрудников. Все больше и больше людей получают надлежащее образование и хотят работать в национальной сфере. управлять. Любой сотрудник должен чувствовать влияние своей работы, чтобы сохранять интерес и непрерывное профессиональное развитие. Поэтому крайне важно активно развивать систему мотивации. Мотивация - необходимый элемент эффективного управления персоналом. Как правило именно собственные мотивы определяют то или иное поведение человека, в том числе в профессиональной сфере [1].

Отношение человека к профессиональной деятельности определяется двумя условными мотивами: внутри одного преобладает направление на достижение поставленной цели, а внешне очень важен сам процесс. Один из доступных способов мотивации сотрудников - это только внешняя мотивация, на внутреннюю мотивацию можно повлиять лишь косвенно, потому что это набор независимо созданных факторов, которые влияют на людей и создают векторы движения.

Внешняя мотивация включает в себя различные формы вознаграждений, продвижения, а также наказаний и дисциплинарных мер. Основными целями мотивации сотрудников являются увеличение результативности и повышение качества трудовой деятельности [2].

Функции мотивации в общей системе деятельности человека:

- побуждение - стимулирование к большей активности; энергия - высвобождение дополнительных ресурсов для выполнения поставленной задачи;

- дозирование - соответствие интенсивности побудителя и количества энергии для работы;

- регулирование - связывание рабочего процесса, а также внешних и внутренних побудителей;

- селекция - блокировка реализации незначительных потребностей и соответствующих мотивов.

- коррекция - изменение деятельности в зависимости от текущей ситуации;

- образование смысла - передача смысла всей деятельности и отдельных ее частей.

Поэтому система мотивации очень важна в других сферах работы и жизни сотрудников. Это объясняет необходимость формулировать параметры для мотивации сотрудников, такие как использование различных мотивационных факторов, гибкость и порядок [3].

Стимулирование эффективности деятельности сотрудников обладает своей спецификой:

- с увеличением интенсивности стимулирования результативность возрастает лишь до определенного уровня, после чего происходит спад;

- при повышении сложности работы требуется снижение уровня мотивации, а избыточная стимуляция может привести к дезорганизации деятельности [4].

Среди различных методов определения формы и типа поощрений ко всем организациям применимы несколько методов:

- деньги - наиболее очевидное внешнее поощрение. При выборе работы важнейшим фактором является уровень заработной платы. Однако постоянное повышение заработной платы экономически невыгодно. Что 
касается страны. Есть еще много недостатков в уровне доходов сотрудников и экспертов. Повышение заработной платы необходимо для решения ряда проблем, в том числе повышения производительности;

натуральный - выражается в получении жилья, наличии льгот на определенные услуги, в том числе путевки в санатории. Зачастую в государственной службе именно такого рода блага являются решающим фактором мотивации сотрудников.

Существуют также негативные стимулы, которые связаны с возможными негативными последствиями и санкциями за ненадлежащее исполнение обязанностей. Однако в настоящее время существует система подготовки национальных специалистов. Сервис предназначен для других методов поощрения, поэтому использование этого метода недопустимо. Коллективное стимулирование направлено на группу сотрудников и обеспечивает механизмы контроля выполнения задач со стороны каждого сотрудника [5].

Таким образом, на сегодняшний день существует целый комплекс различных стимулов для сотрудников гос. службы. Для обеспечения эффективной работы следует сочетать материальные, нематериальные и натуральные виды, а также коллективное стимулирование.

1. Аширов Д.А. Управление персоналом. / Д.А. Аширов - М.: ТК Велби,2019. (гриф) — 220с.

2. Баженова Е. Мотивация и стимулирование на пути к успеху фирмы / Елизавета Баженова. — M.: АСТ, Сова, Харвест, 2018. - 192 с.

3. Верхоглазенко В. Базовые элементы построения механизма оптимального стимулирования труда //Управление персоналом. - 2019. - №3. -С. 23-27.

4. Кошарная Г.Б. Управление персоналом (новые кадровые технологии): Методические указания - Изд.: ПГУ Пенза, 2018. - 219c.

5. Сапронова С.Л. О некоторых основных факторах мотивации и демотивации труда государственных служащих // Научные труды Северо-Западного института. 2012. № 2. С.76-82.

\section{Юсупова Т.А.}

Проблемы взаимодействия государственного и муниципального управления

ФГБОУ ВО «Чеченский государственный университет имени А.А.Кадырова»

(Россия, Грозный)

doi: 10.18411/trnio-11-2021-121

\section{Аннотация}

В данной статье освещаются основные проблемы в области взаимодействия между государством и муниципальным управлением, определяются направления его совершенствования, устанавливается открытый интерактивный режим, обеспечивается поток информации и обеспечивается продуктивная коммуникация между государством и автономными агентствами.

Ключевые слова: государственное управление, муниципальное управление, взаимодействие, система коммуникаций.

\section{Abstract}

This article highlights the main problems in the field of interaction between the state and municipal government, defines the directions for its improvement, establishes an open interactive regime, ensures the flow of information and ensures productive communication between the state and autonomous agencies.

system.

Keywords: public administration, municipal administration, interaction, communication 